\title{
PEMBERDAYAAN MASYARAKAT DESA PENYANGGA TAMAN NASIONAL BERBAK MELALUI PENGUATAN MODAL USAHATANI PADI SAWAH (Oryza Sativa L) \\ (Studi Kasus Desa Simpang Datuk Kecamatan Nipah Panjang Kabupaten Tanjung Jabung Timur)
}

\author{
Asmaida \\ Fakultas Pertanian Universitas Batanghari Jambi \\ Email : asmaida.syandri@yahoo.co.id
}

\begin{abstract}
Berbak National Park is located in the province of Jambi Regency Muara Jambi and Tanjung Jabung Timur District with an area of 162,700 ha and is surrounded by a buffer village, 27th among the village is the village of Simpang Datuk Subdistrict of Tanjung Jabung Regency Nipah Panjang Timur. The village of Simpang Datuk has been getting the program empowerment in rice farming, namely capital strengthening aid farming rice (Oryza Sativa l.) in the form of tool production Hand Tractor and Rice Milling Units of Berbak National Park Hall. This empowerment programme has been carried out from the year 2009 and is expected to show positive results in accordance with the purpose (Berbak National Park Hall, 2014).

The hypothesis of this research is suspected, there is the impact of community empowerment programmes Supporting National Park Village Berbak through strengthening the capital of farming rice (oryza sativa l) against the income of the farmers in the village of Simpang Datuk Subdistrict of Tanjung Jabung Regency Nipah Panjang Timur.

The purpose of this research is to analyze the impact and benefits of community empowerment programmes supporting national park village Berbak through strengthening the capital of farming rice (oryza sativa L) against the income of the farmers in the village of Simpang Datuk Subdistrict of Tanjung Jabung Regency Nipah Panjang Timur. The research method is to use the methods of the survey. In this regard rice farmers as a source of primary data, with data collection techniques are observation, interview and a questionnaire filling terpola and structured in accordance with the needs of the data that refers to the topic and title research. Secondary data source obtained from Agencyrelated institutions, literature-literature and reports. The technique of sampling randomly (random sampling) and the number of samples as much as 39 households of fishermen (RTP) or by $15 \%$ of the total population (262 RTP).

Research data were analyzed using descriptive method quantitativequalitative and interperensi. The first objective of the research is analyzed using descriptive analysis of farmers ' income against rice and continued with statistically testing with test wilkoxon, whereas the second objective is analyzed using descriptive analysis against the benefits of the empowerment program.

Results of the study showed the average income of rice farmers before the activities empowerment through strengthening of the rice farmer capital is $R p$. 14.232.455,-/Ha/MT and after the activities empowerment of the average income of Rp. 18.953.612,-/Ha/MT. There is a change in the income of farmers after the activities empowerment of the average amounting to Rp. 4.721.157,-/Ha/MT
\end{abstract}


(33.17\%) from the prior existence of the empowerment program. The benefits of empowerment programs in the real perceived by farmers only as economic benefits, that they can have the means of production like Hand Tractors and Rice Milling units. In this already occurs, the outpouring of time efficiency of labor and minimize the cost of farming, so as to increase income or standard of kesehjahteraan his life.

Keywords: Rice, Income, Impact, Benefits, Empowerment Program

\begin{abstract}
Abstrak
Taman Nasional Berbak Provinsi Jambi ini terletak di Kabupaten Muara Jambi dan Kabupaten Tanjung Jabung Timur dengan luas 162.700 ha dan dikelilingi oleh 27 desa penyangga, salah satu diantara desa tersebut adalah Desa Simpang Datuk Kecamatan Nipah Panjang Kabupaten Tanjung Jabung Timur. Desa Simpang Datuk tersebut telah mendapatkan program pemberdayaan dalam berusahatani padi sawah, yaitu bantuan penguatan modal usahatani padi sawah (Oryza Sativa L) berupa alat produksi Hand Tractor dan Rice Milling Unit dari Balai Taman Nasional Berbak. Program pemberdayaan ini telah dilakukan dari tahun 2009 dan diharapkan dapat menunjukkan hasil yang positif sesuai dengan tujuan (Balai Taman Nasional Berbak, 2014).

Hipotesis penelitian ini adalah diduga terdapat dampak program Pemberdayaan Masyarakat Desa Penyangga Taman Nasional Berbak melalui penguatan modal usahatani padi sawah (oryza sativa $l$ ) terhadap pendapatan petani di Desa Simpang Datuk Kecamatan Nipah Panjang Kabupaten Tanjung Jabung Timur.

Tujuan penelitian ini adalah menganalisis dampak dan manfaat program pemberdayaan masyarakat desa penyangga Taman Nasional Berbak melalui penguatan modal usahatani padi sawah (oryza sativa $L$ ) terhadap pendapatan petani di Desa Simpang Datuk Kecamatan Nipah Panjang Kabupaten Tanjung Jabung Timur. Metode penelitian adalah menggunakan metode survey. Dalam hal ini petani padi sawah adalah sebagai sumber data primer, dengan tehnik pengumpulan data secara observasi, wawancara dan pengisian kuisioner yang terpola dan terstruktur sesuai dengan kebutuhan akan data yang mengacu pada topik dan judul penelitian. Sumber data sekunder diperoleh dari instansi-instansi terkait, literature-literatur dan laporan-laporan. Teknik pengambilan sampel secara acak (random sampling) dengan jumlah sampel sebanyak 39 rumah tangga nelayan (RTP) atau sebesar 15\% dari jumlah total populasi (262 RTP).

Data penelitian dianalisis menggunakan metode deskriptif kualitatifkuantitatif dan interperensi. Tujuan pertama penelitian dianalisis dengan menggunakan analisis deskriptif terhadap pendapatan petani padi sawah dan dilanjutkan dengan pengujian secara statistik dengan uji wilkoxon, sedangkan tujuan kedua dianalisis dengan menggunakan analisis deskriptif terhadap manfaat dari program pemberdayaan tersebut.

Hasil penelitian menunjukan rata-rata pendapatan petani padi sawah sebelum adanya kegiatan pemberdayaan melalui penguatan modal usaha tani padi sawah adalah sebesar Rp.14.232.455,-/Ha/MT dan setelah adanya kegiatan pemberdayaan rata-rata pendapatan sebesar Rp.18.953.612,-/Ha/MT. Terdapat
\end{abstract}


perubahan pendapatan petani setelah adanya kegiatan pemberdayaan rata-rata sebesar Rp.4.721.157,-/Ha/MT $(33,17 \%)$ dari sebelum adanya program pemberdayaan. Manfaat dari program pemberdayaan yang dirasakan secara nyata oleh petani hanya sebatas manfaat ekonomi, yaitu mereka dapat memiliki alat produksi seperti Hand Tractor dan Rice Milling Unit.Dalam hal ini sudah terjadi efesiensi waktu, curahan tenaga kerja dan memperkecil biaya usahatani, sehingga dapat meningkatkan pendapatan atau taraf kesehjahteraan hidupnya.

Kata Kunci : Padi Sawah, Pendapatan, Dampak, Manfaat, Program Pemberdayaan

\section{PENDAHULUAN}

Taman Nasional Berbak Provinsi Jambi ini terletak di Kabupaten Muara Jambi dan Kabupaten Tanjung Jabung Timur dengan luas 162.700 ha dan dikelilingi oleh 27 desa penyangga, salah satu diantara desa tersebut adalah Desa Simpang Datuk Kecamatan Nipah Panjang Kabupaten Tanjung Jabung Timur (Balai Taman Nasional Berbak, 2014).

Sebagai desa penyangga kawasan Taman Nasional Berbak, Desa Simpang Datuk memiliki keuntungan tersendiri yang tidak dimiliki oleh desadesa lain diantaranya adalah: 1). Memiliki ketahanan budaya yang baik, ini dibuktikan dengan masih ada beberapa nilai tradisi dan kebiasaan khas masyarkat setempat yang bernilai baik yang tetap dilestarikan oleh pemuka adat serta anggota masyarakat lainnya; 2). Telah mendapatkan program pemberdayaan dalam usahatani padi sawah, yaitu bantuan penguatan modal usahatani padi sawah (Oryza Sativa L) berupa alat produksi Hand Tractor dan Rice Milling Unit dari Balai Taman Nasional Berbak sejak dari tahun 2009 sampai sekarang; 3).Memiliki tingkat ketersedian air sepanjang tahun yang berasal dari kawasan hutan Taman Nasional Berbak sehingga kegiatan usahatani padi sawah dapat berjalan dengan baik (Balai Taman Nasional Berbak, 2014).

Berdasarkan uraian diatas maka dilakukan penelitian tentang "Pemberdayaan Masyarakat Desa Penyangga Taman Nasional Berbak Melalui Penguatan Modal Usahatani Padi Sawah (Oryza Sativa L) (Studi Kasus Desa Simpang Datuk Kecamatan Nipah Panjang Kabupaten Tanjung Jabung Timur)”, dengan tujuan penelitian adalah untuk : 1).Menganalisis dampak program pemberdayaan masyarakat Desa Penyangga Taman Nasional Berbak melalui penguatan modal usahatani padi sawah (oryza sativa $L$ ) terhadap pendapatan petani di Desa Simpang Datuk Kecamatan Nipah Panjang Kabupaten Tanjung Jabung Timur. 2).Mengetahui manfaat program pemberdayaan masyarakat Desa Penyangga Taman Nasional Berbak melalui penguatan modal usahatani padi sawah (oryza sativa $L$ ) di Desa Simpang Datuk Kecamatan Nipah Panjang Kabupaten Tanjung Jabung Timur.

Hipotesis yang akan diuji dalam penelitian ini adalah diduga terdapat dampak program Pemberdayaan Masyarakat Desa Penyangga Taman Nasional Berbak melalui penguatan modal usahatani padi sawah (oryza sativa l) terhadap pendapatan di Desa Simpang Datuk Kecamatan Nipah Panjang Kabupaten Tanjung Jabung Timur. 


\section{METODOLOGI PENELITIAN}

Lokasi penelitian ini dilakukan di Desa Simpang Datuk Kecamatan Nipah Panjang Kabupaten Tanjung Jabung Timur dengan pemilihan lokasi secara purposive atau sengaja. Alasan pemilihan daerah tersebut, antara lain: 1). Desa Simpang Datuk Kecamatan Nipah Panjang merupakan salah satu kecamatan di Kabupaten Tanjung Jabung Timur yang memiliki luas lahan, produksi dan produktivitas pertanian padi sawahnya tergolong tinggi, dengan produktivitasnya berada di atas rata-rata produktivitas padi sawah di Kabupaten Tanjung Jabung Timur; 2). Merupakan sentra produksi padi sawah; 3). Di daerah ini telah berjalan program pemberdayaan masyarakat desa penyangga Taman Nasional Berbak melalui penguatan modal usahatani padi sawah (oryza sativa l) berupa alat produksi berupa Hand Tractor dan Rice Milling Unit yang telah berkembang secara positif (Balai Taman Nasional Berbak, 2014).

Metode penelitian yang digunakan adalah menggunakan metode survei. Menurut Silalahi, U. 2010, bahwa survei adalah suatu usaha untuk mendapatkan dan mengumpulan data dan informasi dari berbagai sumber. Dalam hal ini adalah petani padi sawah sebagai sumber data primer, dengan tehnik pengumpulan data secara observasi, wawancara dan pengisian kuisioner yang terpola dan terstruktur sesuai dengan kebutuhan akan data yang mengacu pada topik dan judul penelitian, dan instansi-instansi terkait, literature-literatur sebagai sumber data sekunder.

Dalam pengumpulan data penelitian dilakukan penarikan sampel, Tasri, E,S, (2007), menyatakan sampel adalah kumpulan dari unit sampling yang merupakan subset dari populasi atau bagian tertentu yang dipilih dari populasi. Sampel dapat digunakan dalam penelitian, dengan tujuan untuk menghemat biaya, mempercepat pelaksanaan penelitian, menghemat tenaga, memperluar ruang lingkup penyajian, dan memperoleh hasil yang lebih akurat. Selanjutnya sampel dapat digunakan apabila keadaan subjek populasi homogen. Berdasarkan uraian tersebut, maka digunakanlah sampel dalam penelitian ini. Selanjutnya Winarno, S dalam Tasri E,S (2007), menyatakan bahwa bila populasi cukup homogen, terhadap populasi dibawah 100 dapat digunakan sampel sebesar $50 \%$ dan bila populasi diatas 100 maka besarnya sampel adalah $15 \%$. Berdasarkan pertimbangan uraian diatas maka diambil sampel sebesar 15\% (39 RTP) dari total populasi petani padi sawah (262 RTP), secara acak (simple random sampling).

Dalam menganalisis data penelitian digunakan metode deskriptif kualitatif-kuantitatif dan interperensi untuk menjawab perumusan masalah mengenai bagaimana dampak dan manfaat dari program pemberdayaa masyarakat desa penyangga Taman Nasional Berbak melalui penguatan modal usahatani padi sawah di Desa Simpang Datuk Kecamatan Nipah Panjang Kabupaten Tanjung Jabung Timur. Hasil penelitian yang dikumpulkan ditabulasi dan dihitung ratarata frekuensi dan dipersentasekan.

Adapun analisis secara deskriptif digunakan untuk menganalisis hasil kuesioner yang sudah didapat di lapangan. Hasil analisis kuesioner ini bermanfaat untuk mengetahui bagaimana dampak dan manfaat program pemberdayaa masyarakat desa penyangga Taman Nasional Berbak melalui penguatan modal usahatani padi sawah di Desa Simpang Datuk Kecamatan Nipah Panjang Kabupaten Tanjung Jabung Timur. Analisis yang dilakukan adalah sebagai berikut : 


\section{A. Analisis Dampak Program Terhadap Pendapatan Petani Padi Sawah}

Dalam menganalisis dampak program terhadap perubahan pendapatan petani ini, akan dihitung besarnya pengeluaran, penerimaan dan pendapatan responden sebelum dan setelah adanya program pemberdayaan, selanjunya dihitung persentase peningkatan penerimaan dan pendapatan responden setelah adanya program pemberdayaan. Setelah di hitung besarnya pendapatan sebelum dan setelah adanya program pemberdayaan masyarakat desa penyangga, maka dilanjutkan dengan pengujian hipotesis penelitian yang menyatakan bahwa diduga terdapat dampak atau pengaruh program pemberdayaan Desa Penyangga Taman Nasional Berbak melalui penguatan modal usahatani padi sawah (oryza sativa $l$ ) terhadap pendapatan petani di Desa Simpang Datuk Kecamatan Nipah Panjang Kabupaten Tanjung Jabung Timur. Analisis tersebut menggunakan rumus sebagai berikut :

\section{Untuk penghitungan pendapatan digunakan rumus :}

$\pi_{\mathrm{sb}}=\mathrm{TR}_{\mathrm{sb}}-\mathrm{TC}_{\mathrm{sb}}$ dan $\pi_{\mathrm{st}}=\mathrm{TR}_{\mathrm{st}}-\mathrm{TC}_{\mathrm{st}}$

Dimana :

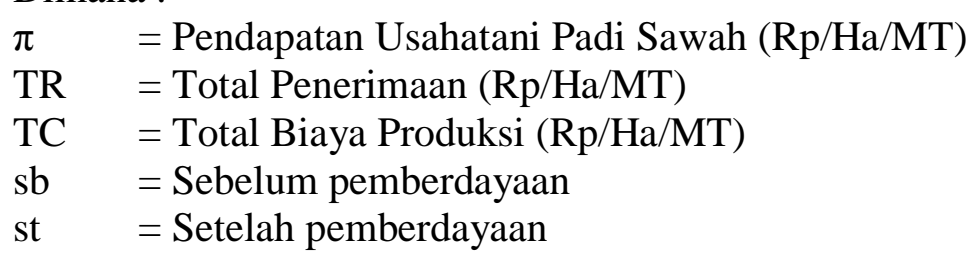

Untuk penghitungan penerimaan digunakan rumus :

$\mathrm{TR}_{\mathrm{sb}}=\mathrm{Y}_{\mathrm{sb}} \cdot \mathrm{Py}_{\mathrm{sb}}$ dan $\mathrm{TR}_{\mathrm{st}}=\mathrm{Y}_{\mathrm{st}} \cdot \mathrm{Py}_{\mathrm{st}}$

Dimana :

$\mathrm{TR}=$ Total penerimaan $(\mathrm{Rp} / \mathrm{Ha} / \mathrm{MT})$

$\mathrm{Y} \quad=$ Produksi yang diperoleh dalam suatu usahatani $(\mathrm{Kg} / \mathrm{Ha} / \mathrm{MT})$

Py = Harga produksi $(\mathrm{Rp} / \mathrm{Kg})$

$\mathrm{sb} \quad=$ Sebelum pemberdayaan

st $\quad=$ Setelah pemberdayaan

Untuk penghitungan biaya produksi atau pengeluaran digunakan rumus : $\mathrm{TC}_{\mathrm{sb}}=\mathrm{FC}_{\mathrm{sb}}+\mathrm{VC}_{\mathrm{sb}}$ dan $\mathrm{TC}_{\mathrm{st}}=\mathrm{FC}_{\mathrm{st}}+\mathrm{VC}_{\mathrm{st}}$

Dimana :

$\mathrm{TC}=$ Total Biaya Produksi $(\mathrm{Rp} / \mathrm{Ha} / \mathrm{MT})$

FC = Fixed Cost atau Biaya Tetap (Rp/Ha/MT)

$\mathrm{VC}=$ Variabel Cost atau Biaya Tidak Tetap $(\mathrm{Rp} / \mathrm{Ha} / \mathrm{MT})$

$\mathrm{sb} \quad=$ Sebelum pemberdayaan

st $\quad=$ Setelah pemberdayaan

Untuk menganalisis persentase peningkatan penerimaan dan pendapatan digunakan rumus :

Peningkatan pendapatan kotor atau penerimaan $=\frac{\text { TRst }- \text { TRsb }}{\text { TRsb }} \times 100 \%$

Peningkatan pendapatan bersih $=\frac{\pi \mathrm{st}-\pi \mathrm{sb}}{\pi \mathrm{sb}} \times 100 \%$

Dimana :

TR : Penerimaan atau Pendapatan kotor

$\boldsymbol{\pi} \quad$ : Pendapatan Bersih

sb : Sebelum pemberdayaan

st : Setelah pemberdayaan 
Untuk menguji hipotesis penelitan digunakan rumus Uji Wilcoxon dengan tingkat kepercayaan sebesar $95 \%$ dengan nilai $\mathrm{z}$ tabel 1,96 dengan rumus (Faisal S, 2005) sebagai berikut:

$$
\begin{aligned}
& z=\frac{\mathrm{T}-\frac{n(n+1)}{4}}{\sqrt{\frac{n(n+1)(2 n+1)}{24}}} \\
& \text { Dimana : } \quad \begin{array}{l}
\mathrm{T}=\text { Nilai yang lebih kecil antara } \mathrm{T}^{+} \text {dan } \mathrm{T}^{-} \\
\mathrm{n}=\text { Jumlah sampel }
\end{array}
\end{aligned}
$$

Hipotesis statistik: $\mathrm{H}_{0}: \pi_{1}=\pi_{2} ; \mathrm{H}_{1}: \pi_{1} \neq \pi_{2}$

Dimana:

$\mathrm{H}_{0}=$ Tidak ada dampak atau pengaruh program pemberdayaan masyarakat Desa Penyangga Taman Nasional Berbak melalui penguatan modal usahatani padi sawah (oryza sativa $L$ ) terhadap pendapatan petani di Desa Simpang Datuk Kecamatan Nipah Panjang Kabupaten Tanjung Jabung Timur.

$\mathrm{H}_{1}=$ Terdapat dampak atau pengaruh program pemberdayaan masyarakat Desa Penyangga Taman Nasional Berbak melalui penguatan modal usahatani padi sawah (oryza sativa L) terhadap pendapatan petani di Desa Simpang

Datuk Kecamatan Nipah Panjang Kabupaten Tanjung Jabung Timur.

Kaidah pengambilan keputusan statistik :

- Jika z hit $>\mathrm{z}$ tabel dengan $\alpha=5 \%$; maka $\mathrm{H}_{0}$ ditolak dan $\mathrm{H}_{1}$ diterima, berarti terdapat dampak atau pengaruh program pemberdayaan masyarakat Desa Penyangga Taman Nasional Berbak melalui penguatan modal usahatani padi sawah (oryza sativa L) terhadap pendapatan petani di Desa Simpang Datuk Kecamatan Nipah Panjang Kabupaten Tanjung Jabung Timur.

- Jika $\mathrm{z}$ hit $\leq \mathrm{z}$ tabel dengan $\alpha=5 \%$; maka $\mathrm{H}_{0}$ diterima dan $\mathrm{H}_{1}$ ditolak, berarti tidak terdapat dampak atau pengaruh program pemberdayaan masyarakat Desa Penyangga Taman Nasional Berbak melalui penguatan modal usahatani padi sawah (oryza sativa $L$ ) terhadap pendapatan petani di Desa Simpang Datuk Kecamatan Nipah Panjang Kabupaten Tanjung Jabung Timur.

\section{B. Analisis Manfaat Program}

Analisis manfaat dilakukan dengan analisis deskriptif. Data-data kualitatif dianalisis dengan menggunakan teori Fenomenologis, artinya bahwa analisis data yang didapatkan dari memahami arti peristiwa dan kaitan-kaitan nya terhadap orang-orang yang berada dalam situasi tersebut. Dengan berusaha untuk masuk ke dalam dunia konseptual para subjek yang diteliti sedemikian rupa sehingga mengerti dan paham apa dan bagaimana suatu pandangan atau pendapat terhadap peristiwa yang terjadi di sekitar mereka dalam kehidupan sehari-hari. Hal ini disebabkan masyarakat dapat menginterprestasikan pengalaman, pandangan, atau pendapat mereka melalui interaksi dengan orang lain. Dengan pendekatan ini, dapat diketahui perilaku utuh dari masyarakat terhadap fenomena yang diteliti.

\section{HASIL PENELITIAN DAN PEMBAHASAN}

A. Dampak Program Pemberdayaan Masyarakat Desa Penyangga Taman Nasional Berbak Melalui Penguatan Modal Usahatani Padi Sawah Terhadap Pendapatan Petani di Daerah Penelitan 


\section{Biaya Produksi Kegiatan Usahatani Padi Sawah}

Biaya produksi yang dihitung dalam kegiatan usahatani padi sawah adalah nilai dari semua korbanan, baik dalam bentuk barang ataupun jasa selama proses produksi. Dalam penenlitian ini biaya yang dihitung adalah biaya yang dikeluarkan sejak kegiatan pengolahan lahan, sampai dengan pengolahan hasil panen atau satu kali periode musim tanam..

Untuk biaya tenaga kerja sebelum adanya kegiatan pemberdayaan masyarakat dihitung berdasarkan konversi dari jumlah Hari Orang Kerja (HOK) dikalikan dengan upah harian yang berlaku di Desa Simpang Datuk tahun 2011 yaitu sebesar Rp. 30.000,-/hari sedangkan untuk menghitung biaya tenaga kerja setelah adanya kegiatan pemberdayaan masyarakat dihitung berdasarkan konversi dari jumlah Hari Orang Kerja (HOK) dikalikan dengan upah harian yang berlaku di Desa Simpang Datuk tahun 2016 yaitu sebesar Rp. 50.000,-/hari. Hal ini disebabkan oleh karena petani menggunakan tenaga kerja yang terdapat di dalam keluarga masing-masing petani dan juga sesama anggota kelompok tani.

Untuk mengetahui jumlah biaya produksi rata-rata yang dikeluarkan petani sebelum dan setelah adanya kegiatan pemberdayaan masyarakat melalui penguatan modal usahatani dalam satu kali musim tanam dapat dilihat pada Tabel 1.

Tabel 1. Rata-Rata Biaya Produksi Usahatani Padi Sawah Di Daerah Penelitian Tahun 2016

\begin{tabular}{|c|c|c|c|c|c|c|c|}
\hline \multirow{3}{*}{ No } & \multirow{3}{*}{ Uraian } & \multicolumn{4}{|c|}{ Jumlah Biaya } & \multirow{2}{*}{\multicolumn{2}{|c|}{ Total }} \\
\hline & & Biaya $T$ & & Biaya Tida & Tetap & & \\
\hline & & $(\mathrm{Rp} / \mathrm{Ha} / \mathrm{MT})$ & $\%$ & $(\mathrm{Rp} / \mathrm{Ha} / \mathrm{MT})$ & $\%$ & $(\mathrm{Rp} / \mathrm{Ha} / \mathrm{MT})$ & $\%$ \\
\hline 1 & Sebelum & $293.570,52$ & 3,50 & 8.097 .564 & 96,50 & 8.391 .135 & 100 \\
\hline 2 & $\begin{array}{l}\text { Setelah } \\
\text { Pemberdayaan }\end{array}$ & $146.785,26$ & 2,06 & 6.979 .090 & 97,94 & 7.125 .875 & 100 \\
\hline
\end{tabular}

Sumber: Data Primer yang telah diolah, Tahun 2016

Berdasarkan Tabel 1 di atas terdapat perbedaan antara total biaya produksi rata-rata sebelum dan setelah adanya kegiatan pemberdayaan masyarakat melalui penguatan modal usahatani padi sawah. Perbedaan disini adalah memberikan arti bahwa dengan adanya pemberdayaan melalui penguatan modal usahatani padi sawah mengakibatkan terjadinya penurunan biaya produksi per hektar per musim tanam sebesar Rp.1.265.260 atau $-15,08 \%$. Hal ini disebabkan oleh adanya perbedaan konversi dari tenaga kerja yang digunakan sebelum dan setelah adanya kegiatan pemberdayaan masyarakat.

\section{Produksi, Harga dan Penerimaan Usahatani Padi Sawah}

Dalam penelitian ini penerimaan petani yang dihitung adalah penerimaan total dari usahatani yang dilakukan oleh petani responden. Harga produksi yang dihitung adalah harga produksi hasil usahatani berupa beras ditingkat petani yaitu seharga ratarata Rp. 8.436,- per Kg.

Untuk mengetahui penerimaan petani rata-rata per musim tanam sebelum dan setelah adanya kegiatan pemberdayaan masyarakat desa penyangga taman nasinal berbak melalui penguatan modal usahatani padi sawah dapat dilihat pada Tabel 2. 
Tabel 2. Rata-Rata Produksi, Harga dan Penerimaan Usahatani Padi Sawah Di Daerah Penelitian Tahun 2016

\begin{tabular}{|c|c|c|c|c|c|}
\hline \multirow[b]{2}{*}{ No } & \multirow[b]{2}{*}{ Uraian } & \multirow{2}{*}{$\begin{array}{c}\text { Sebelum } \\
\text { Pemberdayaan }\end{array}$} & \multirow{2}{*}{$\begin{array}{c}\text { Setelah } \\
\text { Pemberdayaan }\end{array}$} & \multicolumn{2}{|c|}{ Perubahan } \\
\hline & & & & Jumlah & Persentase (\%) \\
\hline 1 & $\begin{array}{l}\text { Produksi } \\
\text { (Kg/Ha/MT) }\end{array}$ & 2.681 & 3.090 & (+) 409 & (+) 15,26 \\
\hline 2 & Harga $(\mathrm{Rp} / \mathrm{Kg})$ & 8.436 & 8.436 & 0 & 0 \\
\hline 3 & $\begin{array}{l}\text { Penerimaan } \\
(\mathrm{Rp} / \mathrm{Ha} / \mathrm{MT})\end{array}$ & 22.623 .590 & 26.079 .487 & (+) 3.455 .897 & (+) 15,28 \\
\hline
\end{tabular}

Sumber: Data Primer yang telah diolah, Tahun 2016

Dari Tabel 2 di atas dapat dilihat bahwa rata-rata produksi dan penerimaan petani terjadi peningkatan dari sebelum ke setelah adanya kegiatan pemberdayaan melalui penguatan modal usahatani padi sawah masing-masing sebesar $15,26 \%$ atau $409 \mathrm{~kg} / \mathrm{Ha} / \mathrm{MT}$ untuk produksi dan 15,28\% atau Rp.3.455.897/Ha/MT untuk penerimaan.

\section{Rata-Rata Pendapatan Usahatani Padi Sawah}

Pendapatan petani adalah seluruh penerimaan yang diperoleh petani setelah dikurangi dengan seluruh biaya produksi yang dikeluarkan dari kegiatan usahatani padi sawah. Untuk mengetahui pendapatan rata-rata petani sebelum dan setelah adanya kegiatan pemberdayaan masyarakat melalui penguatan modal usahatani padi sawah dapat dilihat pada Tabel 3.

Tabel 3 Rata-Rata Pendapatan Usahatani Padi Sawah Di Daerah Penelitian Tahun 2016

\begin{tabular}{|c|c|c|c|c|c|}
\hline \multirow{2}{*}{ No } & \multirow{2}{*}{ Uraian } & \multirow{2}{*}{$\begin{array}{c}\text { Sebelum } \\
\text { Pemberdayaan }\end{array}$} & \multirow{2}{*}{$\begin{array}{c}\text { Setelah } \\
\text { Pemberdayaan }\end{array}$} & \multicolumn{2}{|c|}{ Perubahan } \\
\hline & & & & Jumlah (Rp) & Persentase (\%) \\
\hline 1 & $\begin{array}{l}\text { Penerimaan } \\
\text { (Rp/Ha/MT) }\end{array}$ & 22.623 .590 & 26.079 .487 & (+) 3.455 .897 & (+) 15,28 \\
\hline 2 & $\begin{array}{l}\text { Biaya } \\
(\mathrm{Rp} / \mathrm{Ha} / \mathrm{MT})\end{array}$ & 8.391 .135 & 7.125 .875 & (-) 1.265.260 & (-) 15,08 \\
\hline 3 & $\begin{array}{l}\text { Pendapatan } \\
\text { (Rp/Ha/MT) }\end{array}$ & 14.232 .455 & 18.953 .612 & (+) 4.721 .157 & (+) 33,17 \\
\hline
\end{tabular}

Sumber: Data Primer yang telah diolah, Tahun 2016

Berdasarkan Tabel 3 di atas, rata-rata pendapatan petani padi sawah sebelum adanya kegiatan pemberdayaan masyarakat per hektar per musim tanam adalah sebesar Rp.14.232.455,-. Sedangkan rata-rata pendapatan petani padi sawah setelah adanya kegiatan pemberdayaan masyarakat per hektar per musim tanam adalah Rp. 18.953.612,-. Hal ini menunjukkan bahwa dengan adanya kegiatan pemberdayaan masyarakat, rata-rata pendapatan petani padi sawah per hektar per musim tanam mengalami peningkatan sebesar Rp. 4.721.157,- atau $33,17 \%$.

\section{Perubahan Pendapatan Petani}

Berdasarkan uji statistik yang dilakukan, perubahan pendapatan responden akibat adanya program pemberdayaan masyarakat tani desa penyangga Taman nasinal Berbak melalui penguatan modal usahatani padi sawah di Desa Simpang Datuk kecamatan Nipah Panjang diperoleh nilai $\mathrm{T}+=0$ dan $\mathrm{T}-=779$, maka dari penelitian ini diperoleh nilai $\mathrm{T}$ yang terkecil yaitu $\mathrm{T}+=0$.

Dari uji statistik yang dilakukan dengan tingkat kepercayaan 95\%, diperoleh nilai $\mathrm{z}$ hitung lebih besar dari nilai $\mathrm{z}$ tabel ( $\mathrm{z}$ hitung $|-5,44|>\mathrm{z}$ tabel 
1,96). Dari hasil pengujian tersebut maka $\mathrm{H}_{0}$ ditolak dan $\mathrm{H}_{1}$ diterima yang berarti terdapat pengaruh kegiatan program pemberdayaan masyarakat desa pennyangga Taman Nasional Berbak melalui penguatan modal usahatani padi sawah terhadap perubahan pendapatan responden di Desa Simpang Datuk Kecamatan Nipah Panjang Kabupaten Tanjung Jabung Timur.

\section{B. Manfaat Program}

Manfaat adalah sesuatu yang terkait dengan tujuan akhir dari pelaksanaan kegiatan. Pelaksanaan kegiatan yang dibahas dalam penelitian ini adalah pelaksanaan program pemmberdayaan masyarakat desa penyangga Taman Nasional Berbak melalui penguatan modal usahatani padi sawah.

Manfaat nyata yang dapat dirasakan oleh petani responden dari adanya program pemberdayaan masyarakat desa penyangga Taman Nasional Berbak ini adalah mereka dapat memiliki alat mesin pertanian seperti mesin pembajak lahan sawah untuk pengolahan lahan, mesin perontok padi untuk pemanenan dan peralatan mekanik yaitu Rice Milling Unit untuk mengolah hasil panen. Kegiatan pemanenan hasil usahatani padi sawah sebelum adanya kegiatan pemberdayaan masyarakat menggunakan cara yang tradisional dan dilakukan secara bersamasama (gotong-royong) sesama anggota kelompok tani dengan sistem upah. Setelah adanya kegiatan pemberdayaan ini, kegiatan pemanenan masih dilakukan secara bersama-sama tetapi telah menggunakan teknologi berupa mesin perontok padi, sehingga dalam hal ini sudah terjadi efesiensi waktu, curahan tenaga kerja dan memperkecil biaya usahatani. Selanjutnya pada kegiatan pengolahan hasil usahatani padi sawah dari padi menjadi beras dilakukan dengan menggunakan peralatan mekanik yaitu Rice Milling Unit. Sebelum adanya kegiatan pemberdayaan, maka petani responden harus menyewa alat tersebut untuk mengolah hasil panen mereka.

Berdasarkan uraian di atas, maka setelah adanya program pemberdayaan melalui penguatan modal usahatani padi sawah, petani tidak lagi mengeluarkan sewa alat mesin pertanian dan tergantung kepada orang lain, sehingga petani responden dapat meningkatkan pendapatan atau taraf kesehjahteraan hidupnya.

\section{KESIMPULAN DAN REKOMENDASI Kesimpulan :}

Dari hasil penelitian dan analisis dampak pemberdayaan masyarakat desa penyangga Taman Nasional Berbak melalui penguatan modal usahatani padi sawah (Oryza sativa L) di Desa Simpang Datuk Kecamatan Nipah Panjang Kabupaten Tanjung Jabung Timur dapat disimpulkan sebagai berikut :

1. Rata-rata pendapatan petani padi sawah per hektar per musim tanam sebelum adanya kegiatan pemberdayaan sebesar Rp. 14.232.455,- dan ratarata pendapatan petani setelah adanya kegiatan pemberdayaan melalui penguatan modal usaha tani padi sawah adalah sebesar Rp. 18.953.612,- .

2. Terdapatnya perubahan atau peningkatan pendapatan petani setelah adanya kegiatan pemberdayaan masyarakat melalui penguatan modal usahatani padi sawah yaitu rata-rata per hektar per musim tanam sebesar $33,17 \%$ atau Rp.4.721.157,- dari sebelum adanya program pemberdayaan.

3. Manfaat dari program pemberdayaan yang dirasakan secara nyata oleh petani adalah hanya sebatas manfaat ekonomi, yaitu mereka dapat memiliki alat mesin pertanian seperti mesin pembajak lahan sawah untuk pengolahan 
lahan, mesin perontok padi untuk pemanenan dan peralatan mekanik yaitu Rice Milling Unit untuk mengolah hasil panen. Dalam hal ini sudah terjadi efesiensi waktu, curahan tenaga kerja dan memperkecil biaya usahatani, sehingga dapat meningkatkan pendapatan atau taraf kesehjahteraan hidupnya.

\section{Rekomendasi :}

Beberapa hal yang harus diperhatikan dalam implementasi program pemberdayaan melalui penguatan modal usahatani padi sawah adalah :

1. Dalam kegiatan pemberdayaan masyarakat hendaknya dilakukan kegiatan monitoring dan evaluasi sehingga diperoleh gambaran tentang kemajuan dari kegiatan ekonomi masyarakat tersebut dan kendala-kendala yang dihadapi sehingga kegiatan pemberdayaan masyarakat yang dilakukan dapat berjalan sesuai dengan tujuan dari kegiatan pemberdayaan masyarakat itu sendiri.

2. Agar kegiatan pemberdayaan masyarakat desa penyangga dapat dilaksanakan secara berkesinambungan serta merata kepada desa-desa penyangga yang berada di sekitar kawasan Taman Nasional Berbak.

3. Karena usahatani padi sawah merupakan salah satu usaha andalan keluarga dan merupakan sumber pendapatan terbesar yang di dukung oleh potensi lahan, maka usahatani padi sawah mempunyai prioritas untuk dikembangkan dan perlu perhatian dari pemerintah setempat secara berkelanjutan.

\section{DAFTAR PUSTAKA}

Balai Taman Nasional Berbak. 2010. Laporan Tahunan Balai Taman Nasional Berbak. Jambi.

2014. Laporan Tahunan Balai Taman Nasional Berbak. Jambi.

Faisal S, 2001. Format-format Penelitian Sosial. PT. Raja Grafindo Persada, Jakarta

Giarci, G.G, 2001, Caught in Nets: A Critical Examination of the Use of the Concept of

"Network" in Community Development Studies, Community Development

Journal Vol.36 (1): 63-71, January 2001 , Oxford University Press.

Hernanto. F. 1994. Ilmu Usahatani. Penebar Swadaya. Jakarta.

Hikmat, Harry. 2001. Strategi Pemberdayaan Masyarakat. Humaniora Utama Press Bandung.

Jacobsen Joyce P, 2011. The Economics of Gender. Great Britain, TJ International, Padstow, Corwall: Hongkong

Kartasapoetra. 1988. Marketing Produksi Pertanian dan Industri. Rieke Cipta, Jakarta.

Mac Kinnon, J., K. Mac Kinnon, G. Child dan J. Thorsell, 1993. Pengelolaan Kawasan Yang Dilindungi di Daerah Tropika. Universitas Gadjahmada Press. Jogyakarta.

Man Yee Kan, 2010. Gender asymmetry in the division of labour.

Departement of Sociology University of Oxford

Meentje Simataw,Leonard Simanjuntak,2010 Gender Dan Pengelolaan Megawangi, 2010. Gender Perspective in Early Childhood Care and Development in Indonesia. Report Submitted to The Consultative Group on Early Childhood Care and Development, M A, USA. 
Mulyani, S. 1997. Pendekatan Sistem Kawasan Konservasi Alam Terpadu untuk perkembangan Daerah Penyangga (Studi Kasus di Taman Nasional Siberut). Institut Pertanian Bogor. Bogor.

Najiyati,S, Muslihat, L. dan Suryadiputra, I N. 2005. Panduan Pengelolaan Lahan Gambut Untuk Pertanian Berkelanjutan.Bogor : Wetlands International Indonesia Programme

Nasikun, 2000, Globalisasi dan Paradigma Baru Pembangunan Pariwisata Berbasis Komunitas dalam Fandeli, C dan Mukhlison (eds.), Pengusahaan Ekowisata, Fakultas Kehutanan UGM dan Pustaka Pelajar

Silalahi, U. 2010. Metode Penelitian Sosial. PT.Refika Aditama. Bandung

Soekartawi. 2000. Analisis Usahatani, UI. Pres. Jakarta.

Shinta, Agustina. 2011. Ilmu Usaha Tani. (UB Press), Jakarta.

Singarimbun M dan S. Effendi. 1989. Metode Penelitian Survei Edisi kedua. LP3ES, Jakarta.

Sriyanto, T. 2011. Ketergantungan Masyarakat terhadap Sumber Daya Hutan dan Strategi Pengelolaan Taman Nasional Berbak. Universitas Padjadjaran. Bandung.

Suastika, I Wayan, dkk, 1997. Budi Daya Padi Sawah di Lahan Pasang Surut. Balai Penelitian dan Pengembangan Pertanian. Jakarta

Supriyanto, 2004. Harmonisasi Pemberdayaan Masyarakat Perdesaan Dengan Pembangunan Berkelanjutan, Ekstensia, Deptan RI Vol 19/ Th XI/ 2004

Tasri E,S, 2007. Metodologi Penelitian Ekonomi dan Bisnis. Bung Hatta University Press, Padang

Undang-Undang nomor 5 tahun 1990, Konservasi Sumber Daya Alam Hayati dan Ekosistemnya, Jakarta.

Undang-Undang nomor 41 tahun 1999, Kehutanan, Jakarta.

Winarno S, 1994. Pengantar Penelitian Ilmiah (Dalam MetodeTtehnik). Penerbit Kanisius, Tarsito. Bandung 